\title{
THE STUDY OF RISKS OF HERBAL MEDICINES PRODUCTION BY THE FMEA-ANALYSIS METHOD
}

\author{
V.K.Iakovenko
}

\author{
National University of Pharmacy
}

Key words: risk assessment of quality; FMEA-analysis; herbal medicines; technological process

\begin{abstract}
Identification and assessment of risks arising in the process of manufacture of extraction herbal medicines have been performed. The object of research was the technological process of manufacture of multicomponent tinctures and liquid extracts. Risk analysis of production is based on the results of retrospective validation of manufacture of multicomponent extraction herbal medicines, in particular "Climased" oral drops. When conducting validation the critical stages and parameters of the technological process have been determined, acceptance criteria have been specified. Identification of the possible risks for each critical stage and critical parameter of the technological process has been conducted. Expert assessments have been recorded to the form of quality risk assessment. The results of calculations of the risk priority number (RPN) have allowed to refer possible inconsistencies of the technological process at the stage of extraction to unacceptable risks. Risks arising at the stages of the raw material preparation, purification and filtration of extracts have a great impact. In the process of the risk management at the enterprise the categorization of risks (assessed level of risk) has been carried out, the methods of monitoring, prevention and risk response have been proposed; preventive measures, as well as measures in case of risk occurrence have been developed. To prevent and minimize the possible risks of pharmaceutical production the methodological approaches to functioning of the system of the risk management have been developed taking into account the manufacture of drugs based on the medicinal plant raw material.
\end{abstract}

Under market conditions any enterprise inevitably faces with extraordinary situations and unforeseen events, which should be prevented, or which should be timely responded to. Regardless of the reasons of occurrence of risk situations the desire to reduce the threat and minimize the possible financial losses is natural $[9,10]$.

In this regard, at present the problem of developing the management concept based on the risk management is particularly acute for all departments of a pharmaceutical enterprise, and in particular a manufacturing enterprise; this concept would take into account the latest world achievements, accumulated personal experience and the peculiarities of the domestic business environment. In this case efficient management of the organizational structure is impossible without special methods of analysis based on the theory and practice of the risk management. Therefore, it is very important to take fully into account external and internal factors affecting the nature of the risk management organization at the enterprise, as well as to focus on some directions of development of the risk management for a particular enterprise (with consideration for business profile) $[1,7,9]$.

The ISO standards and the corresponding national standards concerning risk analysis contain several tens of methods of their evaluation. The choice and application of specific methods depend on a number of factors: complexity of the problem, degree of risk uncertainty, the possibility of obtaining quantitative estimates of the input data, etc. $[2,4]$.

The aim of our research was to identify and analyze the risks arising in the process of manufacture of extraction herbal medicines.

\section{Materials and Methods}

The process of identification and assessment of risk situations at pharmaceutical manufacturing enterprises should have a strategic level and be permanent. Timely monitoring of potential threats allows to avoid great losses in the material, financial and labour resources [5].

The object of the study was the technological process of manufacture of multicomponent tinctures and liquid extracts at the premises of Zhytomyr "SCE "Pharmaceutical factory" JSC.

In our study the method of failure modes and effect analysis (FMEA) was used. It is one of the most popular tool of risk assessment included in the general list of tools of Guidelines CT-H. the Ministry of Public Health of Ukraine 42-4.2: 2011 "Medicines. Quality Risk Management (ICH Q9)", and corresponds to the task set. FMEA is intended for potential failure mode evaluation of the process, as well as their potential consequences on the result of the process or product characteristics $[4,11]$.

When processing the quantitative results of control of intermediate and finished products statistical methods of quality control of manufacturing processes were used [3].

Results and Discussion

Risk analysis of production was based on the results of retrospective validation of manufacture of multicomponent extraction herbal medicines, in particular "Climased" oral drops. When conducting validation the critical stages and parameters of the technological process were determined, acceptance criteria were specified. Control charts were composed. The reproducibili- 
Table 1

Risk analysis in the manufacture of liquid extracts and tinctures (FMEA method)

\begin{tabular}{|c|c|c|c|c|c|c|c|c|}
\hline $\begin{array}{l}\text { The process } \\
\text { stage }\end{array}$ & $\begin{array}{l}\text { Controlled } \\
\text { indicator }\end{array}$ & $\begin{array}{c}\text { Consequences } \\
\text { of } \\
\text { noncompliance }\end{array}$ & $\begin{array}{l}\text { Seriousness of } \\
\text { consequences }\end{array}$ & $\begin{array}{c}\text { A possible } \\
\text { cause of } \\
\text { noncompliance } \\
\end{array}$ & Probability & \begin{tabular}{|c|}
$\begin{array}{c}\text { The method of } \\
\text { determination } \\
\text { or control }\end{array}$ \\
\end{tabular} & \begin{tabular}{|c} 
Complexity \\
of \\
identification
\end{tabular} & RPN \\
\hline \multirow[t]{2}{*}{$\begin{array}{l}\text { Grinding and } \\
\text { sieving of the } \\
\text { raw material }\end{array}$} & $\begin{array}{l}\text { Grinding } \\
\text { speed }\end{array}$ & Particle size & 3 & $\begin{array}{c}\text { Malfunction of } \\
\text { equipment }\end{array}$ & 1 & Monitoring & 3 & 9 \\
\hline & $\begin{array}{l}\text { Integrity of } \\
\text { the sieve }\end{array}$ & Particle size & 3 & $\begin{array}{c}\text { Malfunction of } \\
\text { equipment }\end{array}$ & 2 & Visual control & 4 & 24 \\
\hline \multirow[t]{2}{*}{$\begin{array}{c}\text { Preparation } \\
\text { of the } \\
\text { extractant }\end{array}$} & $\begin{array}{l}\text { Time of } \\
\text { mixing }\end{array}$ & $\begin{array}{l}\text { Uniformity of } \\
\text { the extractant } \\
\text { concentration }\end{array}$ & 1 & Operator's error & 1 & Alcoholometry & 1 & 1 \\
\hline & Mixing speed & $\begin{array}{l}\text { Uniformity of } \\
\text { the extractant } \\
\text { concentration }\end{array}$ & 1 & $\begin{array}{l}\text { Malfunction of } \\
\text { equipment }\end{array}$ & 1 & Alcoholometry & 1 & 1 \\
\hline \multirow[t]{2}{*}{$\begin{array}{l}\text { Mixing of the } \\
\text { raw material }\end{array}$} & $\begin{array}{l}\text { Time of } \\
\text { mixing }\end{array}$ & $\begin{array}{l}\text { Uniformity of } \\
\text { the raw material }\end{array}$ & 1 & Operator's error & 3 & Visual control & 1 & 3 \\
\hline & Mixing speed & $\begin{array}{l}\text { Uniformity of } \\
\text { the raw material }\end{array}$ & 1 & $\begin{array}{c}\text { Malfunction of } \\
\text { equipment }\end{array}$ & 3 & Visual control & 1 & 3 \\
\hline \multirow[t]{3}{*}{ Extraction } & $\begin{array}{l}\text { Duration of } \\
\text { extraction }\end{array}$ & $\begin{array}{l}\text { The content } \\
\text { of extractive } \\
\text { substances }\end{array}$ & 5 & Operator's error & 2 & Monitoring & 3 & 30 \\
\hline & $\begin{array}{l}\text { Temperature } \\
\text { of extraction }\end{array}$ & $\begin{array}{l}\text { The content } \\
\text { of extractive } \\
\text { substances, the } \\
\text { concentration } \\
\text { of ethanol }\end{array}$ & 5 & $\begin{array}{c}\text { Malfunction of } \\
\text { the ventilation } \\
\text { and air } \\
\text { conditioning } \\
\text { system }\end{array}$ & 3 & Monitoring & 4 & 60 \\
\hline & $\begin{array}{c}\text { Frequency } \\
\text { and duration } \\
\text { of circulation }\end{array}$ & $\begin{array}{l}\text { The content } \\
\text { of extractive } \\
\text { substances }\end{array}$ & 4 & Operator's error & 3 & Monitoring & 4 & 48 \\
\hline \multirow[t]{2}{*}{$\begin{array}{l}\text { Purification } \\
\text { of the extract }\end{array}$} & Temperature & $\begin{array}{c}\text { Stability of the } \\
\text { drug }\end{array}$ & 4 & $\begin{array}{c}\text { Malfunction of } \\
\text { the ventilation } \\
\text { and air } \\
\text { conditioning } \\
\text { system }\end{array}$ & 2 & Monitoring & 3 & 24 \\
\hline & Time & $\begin{array}{l}\text { Stability of the } \\
\text { drug }\end{array}$ & 4 & Operator's error & 2 & Monitoring & 3 & 24 \\
\hline \multirow[t]{2}{*}{ Filtration } & Pressure & $\begin{array}{c}\text { Specification } \\
\text { noncompliance }\end{array}$ & 2 & $\begin{array}{c}\text { Malfunction of } \\
\text { equipment }\end{array}$ & 2 & Monitoring & 1 & 4 \\
\hline & Filter material & $\begin{array}{l}\text { Change of } \\
\text { qualitative and } \\
\text { quantitative } \\
\text { indicators }\end{array}$ & 4 & $\begin{array}{l}\text { Violation of the } \\
\text { procedure }\end{array}$ & 1 & Visual control & 4 & 16 \\
\hline
\end{tabular}

ty index calculated and the process capability index indicate potential risks to product quality required identification and decision making for their reduction [6].

The FMEA method is based on listing all potential effects (possible failures) with its subsequent analysis and numerical evaluation. Either heads of departments or a dedicated team are engaged in risk management. At "SCE "Pharmaceutical factory" JSC a permanent group of experienced professionals was formed, their official duties referred to the activities of the entire enterprise. The main fixed team included the production manager, the quality system coordinator, the head of Quality Control Department, the head of Research Centre, the process quality control engineer, the mechanic engineer of Production Supporting Services. Additionally the workshop supervisor and foremen of the phytochemical department were included in the team.
In the process of the risk management at the enterprise the following activities were implemented: identification of risks (the fullest list of possible risks being specific to each production stage was determined) was conducted; categorization of risks (assessed level of risk) was carried out when each risk was assigned one of three categories that affect the monitoring method, prevention and response to risk; preventive measures and actions in case of risk occurrence were developed.

After the initial compilation of the list of risks they were classified and evaluated. Each failure was estimated according to three criteria: severity (criticality) of failure, frequency (probability) of occurrence of this defect, possibility (complexity) of identification. To assess these criteria the 5-point rating system was used. The final result is the composite index - risk priority number (RPN), which is equal to the product of scores of 
Efficiency criteria of the risk management

\begin{tabular}{|c|l|l|l|}
\hline Project class & \multicolumn{1}{|c|}{ Effective } & \multicolumn{1}{c|}{ Poorly effective } & \multicolumn{1}{c|}{ Ineffective } \\
\hline High-risk & $\begin{array}{l}\text { Less than 10\% of risks are } \\
\text { implemented }\end{array}$ & $\begin{array}{l}\text { Less than } 25 \% \text { of risks are } \\
\text { implemented }\end{array}$ & $\begin{array}{l}\text { More than25 \% of risks are } \\
\text { implemented }\end{array}$ \\
\hline Risks & $\begin{array}{l}\text { Less than } 20 \% \text { of risks are } \\
\text { implemented }\end{array}$ & $\begin{array}{l}\text { Less than } 50 \% \text { of risks are } \\
\text { implemented }\end{array}$ & $\begin{array}{l}\text { More than } 50 \% \text { of risks are } \\
\text { implemented }\end{array}$ \\
\hline Medium risks & $\begin{array}{l}\text { Less than } 30 \% \text { of risks are } \\
\text { implemented }\end{array}$ & $\begin{array}{l}\text { Less than } 60 \% \text { of risks are } \\
\text { implemented }\end{array}$ & $\begin{array}{l}\text { More than } 60 \% \text { of risks are } \\
\text { implemented }\end{array}$ \\
\hline Low risks & $\begin{array}{l}\text { Less than } 50 \% \text { of risks are } \\
\text { implemented }\end{array}$ & $\begin{array}{l}\text { Less than } 75 \% \text { of risks are } \\
\text { implemented }\end{array}$ & $\begin{array}{l}\text { More than } 75 \% \text { of risks are } \\
\text { implemented }\end{array}$ \\
\hline
\end{tabular}

three specified criteria. At the same time the enterprise sets for itself the limits (norms, level) of risk that can be taken to achieve the desired parameters $[4,8]$.

Guided by the knowledge and experience the team performed identification of possible defects for each critical stage and the critical parameter of the technological process. Expert assessments were recorded to the form of the quality risk assessment (Tab. 1).

The quantitative risk assessment is more acceptable, but it also requires determination of the risk assessment scale for decision making on further action [1]. In accordance with the 5-point rating system chosen the risk priority number can vary from 1 to 125 . The results of the calculations presented in Table allow to refer possible inconsistencies of the technological process at the stage of extraction to unacceptable risks ( $R P N>40)$. Risks arising at the stages of the raw material preparation, purification and filtration of extracts have a great impact $(39>\mathrm{RPN}>15)$.

To prevent and minimize the possible risks of pharmaceutical production the methodological approaches to functioning of the system of the risk management of a pharmaceutical manufacturing enterprise (the manufacture of a drug based on the medicinal plant raw material) have been developed.

In the process of manufacture the staff that is responsible for risk monitors the criteria, which may indicate approaching to the conditions of the risk occurrence. When determining the risk factors the current values are checked and compared with the threshold values signaling the risk occurrence. When revealing a trend in a particular indicator and approaching to the limited value the staff that is responsible for risk conducts preventive measures. If measures to prevent the risk are not effective and the risk occurs, the staff carries out the planned actions of risk response, and further monitoring of the problem is carried out on a daily basis.

To understand and perceive the level (efficiency) of the risk management activities organized the efficiency criteria of the risk management are given in Tab. 2 .
In addition to monitoring the risk management efficiency the work on updating the database of the known risks is in progress. For this purpose any information that can help in the procedure of the risk management in future projects is added to the database. If risks, which descriptions are not in the database, are identified in the production process, then a full description of these risks are entered into the database.

If the project is successfully used information on the known risks and improvement of the procedures for preventing and responding have also been made, or any other significant corrections have been introduced in the risk passport led to more effective risk management (the risk should not be appeared on the project), then all changes are added to the database risks.

If changes were made, however, the risk in the process of work on the project still appeared, a more thorough analysis of the causes of risk should be conducted with a critical assessment of the changes in standard procedures.

\section{CONCLUSIONS}

The research conducted has allowed to identify and classify the main types of risks, determine the probability of their occurrence, assess the degree of their influence on the production process and parameters of work of a pharmaceutical enterprise: falling beyond the budget, failure to meet the deadline, reduction in the quality of the products produced. The results obtained has allowed to improve the risk management system at the enterprise, namely to develop the basic measures for prevention of risks, algorithms of control conducting, points of tighten control. The measures proposed has allowed to prevent or reduce the possible losses, as well as improve one of the main indicators of competitiveness of a pharmaceutical enterprise - the quality of the final product. The risk management framework developed (sequence of operations) at the stage of manufacture of a drug based on the medicinal plant raw material is in the basis of functions of persons or department responsible for the risk management at the enterprise and for the quality of products.

\section{REFERENCES}

1. Александров А.В. // Фармац. отрасль. - 2011. - №5 (28). - С. 116-119.

2. ДСТУ ISO 9001:2009. Системи управління якістю. Вимоги (ISO 9001:2008, IDT). - Вид. офіu. - K.: Держспоживстандарт України, 2009. - 26 с. 
3. Ефимов В.В., Барт Т.В. Статистические методы в управлении качеством продукиии: Учебное пособие. - M.: КНОРУC, 2006. -172 c.

4. Ляпунов М., Безугла О., Соловйов О. та ін. Настанова СТ-Н МОЗУ 42-4.2:2011 «Лікарські засоби. Управління ризиками для якості (ICH Q9)». - К.: МОЗ Украӥни, 2011. - 36 с.

5. Посилкіна О.В., Деренська Я.М., Костюк Г.В. Управління проектами в фармацевтичному виробництві. - Х.: НФаУ, 2010. - 544 c.

6. Яковенко В.К., Вишневский И.А., Георгияни В.А. и др. // Вісник фармації. - 2013. - №1 (39). - С. 37-43.

7. Adama S., Suzzia D., Radekea Ch. et al. // Eur. J. of Pharmac. Sci. - 2011. - Vol. 42, Iss. 1-2. - P. 106-115.

8. Davie J.L. An analysis of risk perception and the RPN index within Failure Modes and Effects Analysis. ProQuest, 2008. - 123 p.

9. Inoue H., Yamada Sh., // Intern. J. of Quality and Service Sci. - 2010. - Vol. 2, Iss. 3. - P. 369-382.

10. Yuecheng Lv., Liang Yi // J. of Chemical and Pharmac. Res. - 2014. - Vol. 6 (6). - P. 1116-1123.

11. Zimmermann H.F., Hentschel N. // PDA J. of Pharmac. Sci. and Technol. - 2011. - Vol. 65.5. - P. 506-512.

\section{ДОСЛІДЖЕННЯ РИЗИКІВ ВИРОБНИЦТВА РОСЛИННИХ ЛІКАРСЬКИХ ЗАСОБІВ МЕТОДОМ FMEA-АНАЛІЗУ \\ В.К.Яковенко \\ Ключові слова: оцінка ризиків якості; FMEA-аналіз; рослинні лікарські засоби;} технологічний процес

Проведено ідентифрікацію та оцінку ризиків, що виникають у процесі виробництва екстракційних рослинних лікарських засобів. Об'єктом досліджень був технологічний процес виробництва багатокомпонентних настойок та рідких екстрактів. Аналіз ризиків виробництва базувався на результатах проведеної ретроспективної валідації виробництва багатокомпонентних екстракційних рослинних препаратів, зокрема крапель оральних «Клімасед». При проведенні валідації були визначені критичні стадії та параметри технологічного процесу, встановлені критерії прийнятності. Була проведена ідентифрікація можливих ризиків для кожної критичної стадії та критичного параметра технологічного процесу. Експертні оцінки заносились до фоормуляру оцінки ризиків якості. Результати розрахунків підсумкового коефріцієнту ризику (RPN-risk priority number) дозволили віднести до неприйнятних ризиків можливі невідповідності технологічного процесу на стадії екстрагування. Суттєвий вплив мають ризики, що виникають на стадії підготовки сировини, очистки та фрільтрування екстрактів. У процесі управління ризиками на підприємстві було здійснено категоризацію ризиків (оцінка рівня ризику), запропоновані методи моніторингу, запобігання і реагування на ризик; розроблені профрілактичні заходи, а також заходи на випадок реалізації ризику. 3 метою профрілактики та мінімізації можливих ризиків фрармацевтичного виробництва розроблені методологічні підходи до функціонування системи ризик-менеджменту з урахуванням особливостей виробництва лікарських препаратів на основі лікарської рослинної сировини.

\section{ИССЛЕДОВАНИЕ РИСКОВ В ПРОИЗВОДСТВЕ РАСТИТЕЛЬНЫХ ЛЕКАРСТВЕННЫХ СРЕДСТВ МЕТОДОМ FМЕА-АНАЛИЗА \\ В.К.Яковенко \\ Ключевые слова: оценка рисков качества; FMEA-анализ; растительные лекарственные средства; технологический процесс}

Проведена идентифрикация и оценка рисков, возникающих в процессе производства экстракционных растительных лекарственных средств. Объектом исследований был технологический процесс производства многокомпонентных настоек и жидких экстрактов. Анализ рисков производства базировался на результатах проведенной ретроспективной валидации производства многокомпонентных экстракционных растительных препаратов, в частности капель оральных «Климасед». При проведении валидации были определены критические стадии и параметры технологического процесса, установлены критерии приемлемости. Была проведена идентификация возможных рисков для каждой критической стадии и критического параметра технологического процесса. Экспертные оценки заносились в формуляр оценки рисков качества. По результатам расчетов ранга приоритетности риска (RPN-risk priority number) к неприемлемым рискам отнесены возможные нарушения технологического процесса на стадии экстрагирования. Существенное влияние на качество имеют риски, возникающие на стадии подготовки сырья, очистки и фильтрации экстрактов. В процессе управления рисками на предприятии была осуществлена категоризация рисков (оценка уровня риска), предложены методы мониторинга, предотвращения и реагирования на риск; разработаны профилактические мероприятия, а также мероприятия на случай реализации риска. С целью профрилактики и минимизации возможных рисков фрармацевтического производства разработаны методологические подходы к фуункционированию системы рискменеджмента с учетом особенностей производства лекарственных препаратов на основе лекарственного растительного сырья. 